\title{
Behavioural and anticonvulsant properties of methanol extract of the stem bark of Stereospermum kunthianum Cham in mice
}

\author{
Lydia Doosuur IOR*, Bulus Nankwat PEKUK and Sunday Oritsetimenyin OTIMENYIN \\ Department of Pharmacology, Faculty of Pharmaceutical Sciences, University of Jos, Jos. Nigeria.
}

Received $7^{\text {th }}$ September 2020; Accepted 28th December 2020

\begin{abstract}
Decoctions of Stereospermum kunthianum Cham are used in Nigeria's folk medicine for the management of epilepsy and their efficacies are commonly applauded among the rural communities of northern Nigeria. The aim of the study is to investigate the behavioural and anticonvulsant properties of the standardized methanol extract of the stem bark of S. kunthianum, in order to scientifically establish its potential values in the management of convulsive and anxiety disorders. The oral median lethal dose $\left(\mathrm{LD}_{50}\right)$ is determined in mice. The anticonvulsant effect of $S$. kunthianum was evaluated on pentylenetetrazole induced-seizure in mice and phenobarbitone induced-sleep was used to examine the sedative effect of the extract, marble burying test was performed to investigate the anxiolytic effect. The oral $\mathrm{LD}_{50}$ of the extract was assessed to be greater than $5000 \mathrm{mg} / \mathrm{kg}$. S. kunthianum significantly extend the onset of pentylenetetrazole induced seizure and reduced the episodes as well. It shortened the onset and prolonged the duration of Phenobarbitone-induced sleep, it also significantly decreased the number of marbles buried by the mice, signifying anxiolytic effect. Our study offers scientific proof that the extract may possess psychoactive principles with potential anticonvulsant and anxiolytic properties.
\end{abstract}

Keywords: Anticonvulsant, Anxiolytic, Sedative, Mice, Stereospermum kunthianum

\section{INTRODUCTION}

Epilepsy is a term used to describe a chronic brain syndrome of various aetiologies, categorized by recurring seizures due to excessive discharge of cerebral neurons. It is related to a variety of clinical symptoms (e.g. disturbances of consciousness, movement and sensation) and laboratory manifestations of electroencephalographic (EEG) changes such as hyper synchronization of electrical activity of the brain [1]. Epilepsy is the commonest chronic neurological illness in the world, it affects individuals of all race, ages and social class. It is projected that over 50 million people suffer from epilepsy worldwide, up to $75 \%$ of the sufferers live in resource-limited countries with very little access to medical services or treatment [2,3]. Although epilepsy is an illness that is treatable many are unable to pay for treatment due to poverty and lack of resources. Therefore, it is essential to evaluate plants that are readily available in our setting for safety and efficacy to enable people living in the resource-limited areas to have access to safe and efficacious drugs within their location. Stereospermum kunthianum (Cham, Sandrine

*Correspondence. E-mail: shalhonal@unijos.edu.ng Tel: +234-8036098383.

ISSN 0189-8442

(cc) BY-NC 2021. Published by Faculty of Pharmaceutical Sciences, University of Jos, Nigeria. Under Creative Commons Attribution-Non-Commercial 4.0 International License. https://creativecommons.org/licenses/by-nc/4.0/ 
Petit), is a medicinal plant extensively used by the people of Sudano-Guinea as remedy against cough, rheumatism, ulcers, leprosy and respiratory infection [4]. Decoctions of the stem back is recognized to have antiseptic and diuretic properties. The isolation and xanthine oxidase inhibitory effect of the plant secondary metabolites has been described [5]. A decoction of the stem-bark of the plant is used in treating venereal diseases; gonorrhoea, diarrhoea and dysentery. It is also used in the management of ulcers, skin eruptions, leprosy and pneumonia [5]. It is also used for the treatment of epilepsy and psychosis in northern Nigeria, though this effect has not been verified scientifically, this formed the basis of the study.

\section{EXPERIMENTAL METHODS}

Stem bark of $S$. kunthianum was collected from a traditional medicine practitioner; Pastor Sati from Jos North Local Government Area of Plateau State, Nigeria. The plant was identified and authenticated by Mr. J. J. Azila of the herbarium unit of the Federal College of Forestry, Jos. The bark was split, cleaned, air dried for 2 weeks and grounded into a coarse powder using a pestle and mortar. One hundred grams (120 g) of the coarse powder was exhaustively extracted with $600 \mathrm{ml}$ of methanol using a Soxhlet extractor for $72 \mathrm{~h}$ at room temperature. The solvent was removed under reduced pressure using a rotary evaporator and it gave a yield of $50.4 \mathrm{~g}(42 \%)$ (w/w). Male and female Swiss albino mice (25-30 g), acquired from the Animal house of the Department of Pharmacology, Faculty of Pharmaceutical Sciences, University of Jos were used. All animals were kept in standard conditions of temperature $\left(23^{\circ} \mathrm{C}\right)$ and light (12/12 h light/dark cycle), and fed with standard feed and water ad libitum. The mice were approved for use by the institutional ethics committee after reviewing the protocol for good laboratory practice and animal handling, which is in agreement with the
National Institutes of Health Guide for the Care and use for Laboratory animals (NIH Publications No. 80-23, revised 1996). All efforts were made to reduce the number of mice used and their suffering.

Drugs and treatment. The following drugs were used: pentylenetetrazole powder, were purchased from Sigma Chemical Co. Ltd, USA, and diazepam injection from Roche Product Ltd. Abuja regional office, Nigeria. $S$. kunthianum bark extract (SKBE) was resuspended in physiological saline solution which was also used as solvent for the other drugs. All solutions were administered intraperitoneally (ip) at a volume of $5 \mathrm{~mL} / \mathrm{kg}$ body weight.

Acute toxicity study. The oral median lethal dose $\left(\mathrm{LD}_{50}\right)$ of the extract was accessed in mice using the method of Lorke [6]. Nine mice were selected and weighed. They were randomly divided into three groups of three mice each. Animals in each group received oral dose of 10,100 , and $1000 \mathrm{mg} / \mathrm{kg}$ of the aqueous extracts respectively and were observed for signs of toxicity and death for a duration of 24 hours. In the $2^{\text {nd }}$ phase of the test, a dose of $1,600,2,900$ and $5000 \mathrm{mg} / \mathrm{kg}$ was administered. The Lethal dose $\left(\mathrm{LD}_{50}\right)$ was calculated as the square root of the products of the maximum dose that did not kill the animals and the minimum dose that killed the animals. The anticonvulsant effects of SKBE were evaluated in mice using the method described by Bhutada et al [7] with slight modifications. Mice were kept overnight in transparent mice cages in the laboratory to acclimatize to their new environment before commencing the experiment. Pentylenetetrazole (PTZ, 85 $\mathrm{mg} / \mathrm{kg}$ ), a standard convulsant agents; was used to induce seizures in the mice. Phenobarbitone (PBT, $30 \mathrm{mg} / \mathrm{kg}$ ) was used as the reference anticonvulsant drugs for comparison. The mice were observed for convulsion for a period of $1 \mathrm{~h}$ post-treatment with PTZ, the onset and episodes of seizures were noted, seizures manifested as tonic hind 
limb extension. The ability of the extract (SKBE; $200-800 \mathrm{mg} / \mathrm{kg}$ ) to prevent or prolong the latency of seizure considered an indication of the anticonvulsant activity [8]. Mice were observed for mortality within $24 \mathrm{~h}$. All experiments were done between $9.00 \mathrm{~h}$ and $16.00 \mathrm{~h}$ in a quiet room.

Phenobarbitone-induced sleep in mice. This test was carried out in 5 groups of 5 mice, which were treated as follows: group one were administered saline, another group received diazepam $(20 \mathrm{mg} / \mathrm{kg})$ and three groups received SKBE (200-800 $\mathrm{mg} / \mathrm{kg})$. Phenobarbitone $(70 \mathrm{mg} / \mathrm{kg})$ was administered to all the mice thirty minutes post-drug administration. The mice were individually observed for the onset and duration of sleep, with the criterion for sleep being loss of righting reflex [9], shown by the animals' inability to return to an erect position on all four limbs after being mildly turned sideways. The interval between loss and recovery of righting reflex was considered as the duration of the hypnotic effect.

Evaluation of anxiolytic activity. A cage (16 $\times 10 \times 5$ inches) was filled to about $5 \mathrm{~cm}$ deep with husk bedding material that was uniformly dispersed into a flat surface across the whole cage. Animals were randomly distributed into 5 groups of 5 mice each in a cage measuring 16 X $10 \times 5$ inches. The first group received saline $(5 \mathrm{~mL} / \mathrm{kg})$; the next three groups were administered SKBE at doses of 200, 400 and $800 \mathrm{mg} / \mathrm{kg}$ respectively. The last group received fluoxetine $10 \mathrm{mg} / \mathrm{kg}$. The animals were habituated in the first phase of the test, they were individually placed in the cage without any marbles and left to explore it for $20 \mathrm{~min}$ before they are removed. During the testing phase, twenty glass marbles $(1.5 \mathrm{~cm}$ in diameter) were evenly spaced in a $4 \times 5$ grid on top of the bedding. Each mouse was then placed in the cage and allowed to explore it for $20 \mathrm{~min}$. At the end of the $20 \mathrm{~min}$ period, mice were removed from the cage and the number of marbles buried with bedding up to $2 / 3$ of their depth were noted.

Statistical analysis. All quantitative data were analysed using the Graph Pad Prism ${ }^{\circledR}$ software (version 6).The data were expressed as mean \pm standard error of the mean (SEM). Statistical differences between control and treated were determined by two way analysis of variance (ANOVA) and one way ANOVA in the marble burying test, with Newman-Keuls post hoc test. Significance was set at $p<0.05$.

\section{RESULTS}

Lethal effects were not observed after the oral administration of the methanol extract at doses of 1600, 2900 and $5000 \mathrm{mg} / \mathrm{kg}$. The oral. $\mathrm{LD}_{50}$ of SKBE in mice was estimated to be greater than $5000 \mathrm{mg} / \mathrm{kg}$. Effect of methanol stem bark extract of $S$. kunthianum on pentylenetetrazole induced convulsion in Mice; Pretreatment with SKBE produced a dose-dependent protection against PTZinduced tonic seizures and mortality in mice. Methanol extract of SKBE 200, 400, and 800 $\mathrm{mg} / \mathrm{kg}$ significantly $(\mathrm{p}<0.05)$ attenuated the convulsive effect induced by PTZ. (Fig. 1). Animals treated with Phenobarbitone (70 $\mathrm{mg} / \mathrm{kg}$ ) showed loss of righting reflex. SKBE $(200,400$ and $800 \mathrm{mg} / \mathrm{kg}$ ) significantly $(\mathrm{p}<0.05)$ shortened the onset and prolonged the duration of phenobarbitone-induced sleep in mice (Fig. 2). Methanol extract of SKBE at 200,400 and $800 \mathrm{mg} / \mathrm{kg}$ significantly ( $\mathrm{p}<0.05$ $\mathrm{mg} / \mathrm{kg}$ ) attenuated the defensive burying of the mice, indicating anxiolytic effect of the extract (Fig 3)

\section{DISCUSSION}

The result obtained in this study indicated that the stem bark of $S$. kunthianum is safe for consumption and possess psychoactive principles with potential usefulness in the management of convulsive, insomnia and anxiolytic disorders, SKBE dose dependently produced significant increase in the onset of convulsion and reduced the 
episodes of convulsion respectively compared to the control, it potentiated phenobarbitoneinduced sleep and decrease significantly marble burying behaviour in mice. The acute toxicity study indicated that the stem bark extract of S. kunthianum at a dose of 5000 $\mathrm{mg} / \mathrm{kg}$ showed no observable signs of toxicity or mortality in mice, signifying its apparent safety $[10,11]$. SKBE significantly protected mice against PTZ induced seizures, by dose dependently delaying the onset and decreasing the episodes of myoclonic jerks and prolonging the latency of tonic seizures. Even though the mechanisms of PTZ-induced seizures is not very clear, studies have indicated that PTZ induces seizures by blocking the major inhibitory pathways facilitated by the major inhibitory neurotransmitter GABA, at all levels of the CNS [12-14]. It was also observed that PTZ induced seizures, can be blocked by standard antiepileptic drugs such as diazepam and phenobarbitone that are believed to act by augmenting GABA-mediated inhibition in the brain $[15,16]$. A number of electrophysiological and biochemical data also supported the role of the glutamatergic mechanism in PTZ-induced seizures. The stimulation of N-methyl D-aspartate (NMDA) receptor system seems to be involved in the initiation and proliferation of PTZ-induced seizures [17, 18]. Therefore, drugs such as felbamate that block glutamatergic excitation propagated by NMDA receptor have shown anticonvulsant activity against PTZ-induced seizures [15, 19]. Henceforth, the anticonvulsant effects of SKBE seen in this study against PTZ induced seizures might be attributed to blockade of glutamatergic neurotransmission facilitated by the NMDA receptor.

The extract at all doses used was able to significantly shorten the onset and prolong the duration of phenobarbitone-induced sleep in mice thus confirming the sedative properties of SKBE. Endogenous neurotransmitters in the brain particularly dopamine, norepinephrine, acetylcholine, serotonin, GABA, histamine and neuropeptides have been observed to play significant roles in sleep mechanisms $[20,21]$. The effects of the extract on phenobarbitoneinduced sleep in mice may be ascribed to its potential interactions with some of the abovementioned central neurotransmitters involved in sleep regulation [22].

One of the distinctive behaviours of rodents, either in their natural environment or in laboratory settings, is known as 'defensiveburying', it refers to the act of covering the material that are on the surface of the cage, with normal movement of the forelegs, in order to hide the confined sources of aversive stimulus or possible danger [23]. This behaviour is also elicited in the presence of apparently harmless substances, such as marbles used in the behavioural test, this has made some authors to query the defensive nature of this behaviour [10]. However, previous studies have revealed that clinically active anxiolytic drugs suppress the defensive burying response in rodents, making this behaviour an index of anxiety in preclinical studies of neurobiology and pharmacology of this human emotion [23]. For this reason the Marble-burying test is used widely to study anxious behaviour in rats and mice, and lately to assess the compulsive behaviour related to obsessive-compulsive disorder [24]. Fluoxetine a selective serotonin reuptake inhibitor (SSRI) was used as anxiolytic agent based on the observation that preclinical and clinical studies suggest the existence of a neurobiological connection between emotional and cognitive processes. Therefore, anxiety disorders may arise due to excessive manifestation of aversive memories. Clinically active anxiolytics, may therefore suppress anxiety through a disruption of the association between emotion and cognition. Both animal and human research, present evidence in support of this theory [25]. 


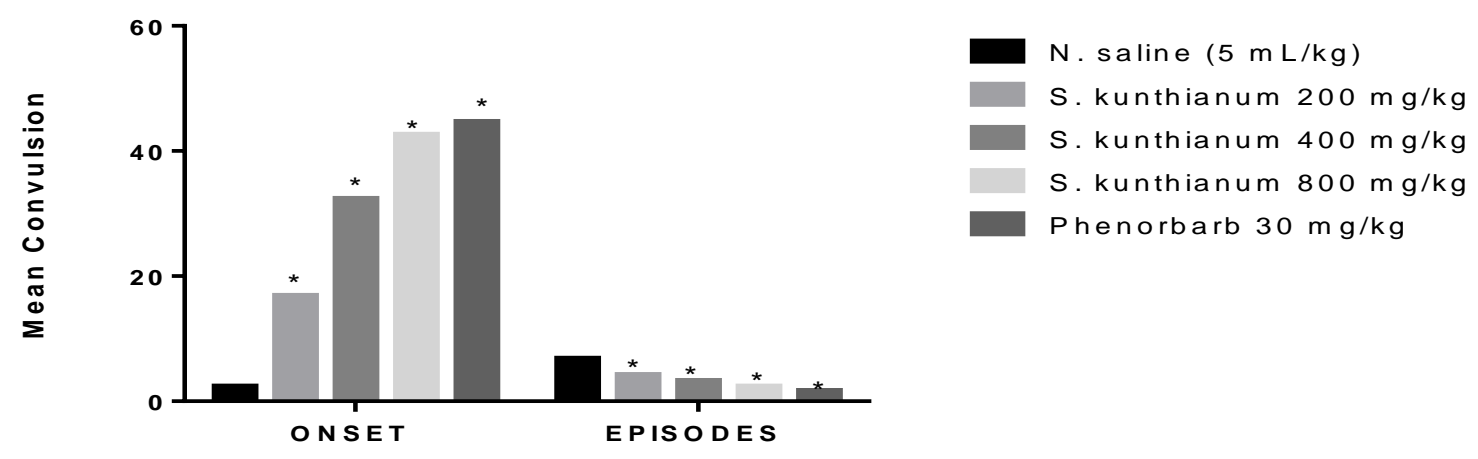

Treatm ent

Fig 1. Effect of Methanol Stem Bark Extract of S. kunthianum on Pentylenetetrazole Induced Convulsion in Mice. $(*=$ significantly different compared to Normal Saline $(\mathrm{p}<0.05)$. (Values were expressed as mean $\pm \mathrm{SEM}), \mathrm{N}=5$
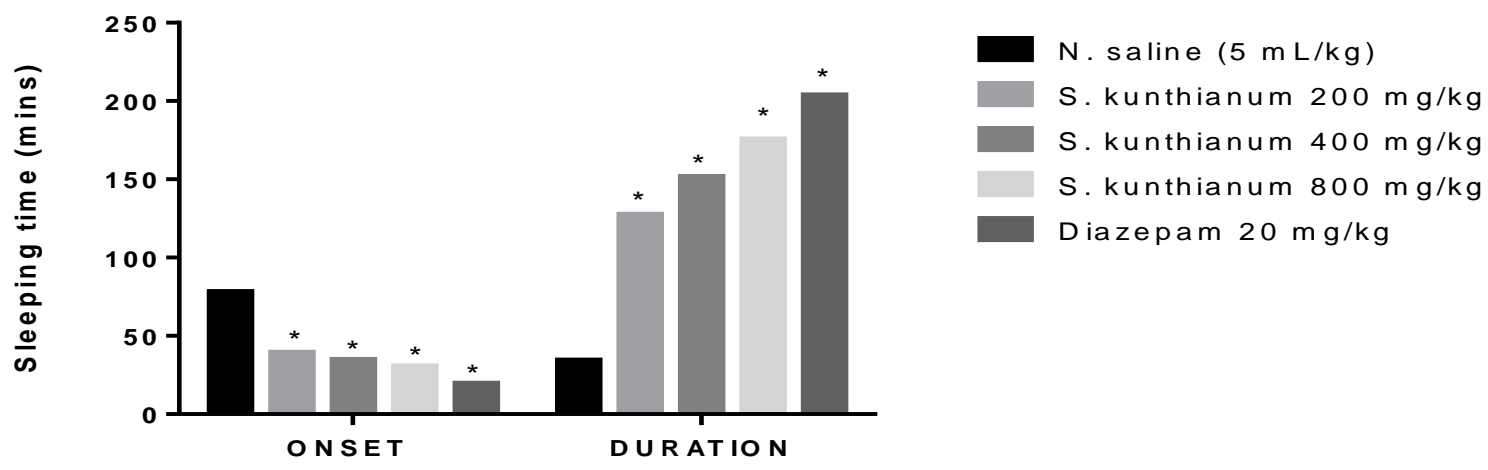

Fig 2. The Effect of Methanol Extract of $S$. Kunthianum on Phenobarbitone $(70 \mathrm{mg} / \mathrm{kg})$ Induced Sleeping Time. $(*=$ significantly different compared to Normal Saline $(\mathrm{p}<0.05)$. Values are expressed as mean $\pm \mathrm{SEM}) \mathrm{N}=5$

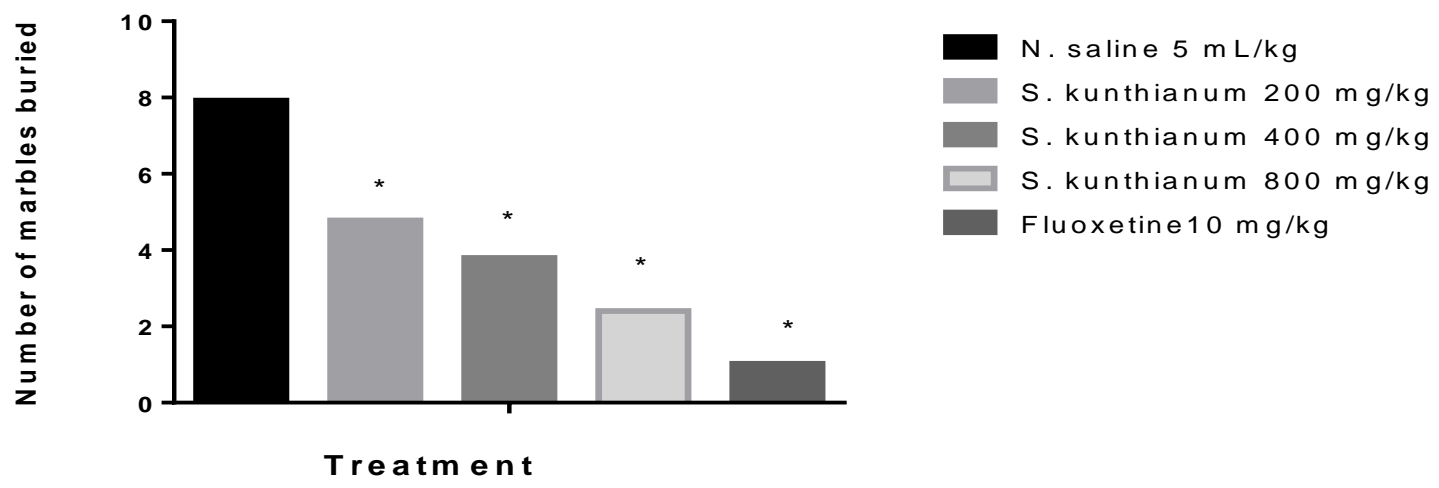

Fig 3. Effect of Methanol Extract of S. kunthianum on Marble Burying Test in mice (anxiolytic effect). (*= significantly different from Normal Saline $(\mathrm{p}<0.05)$; Values are expressed as mean $\pm \mathrm{SEM}), \mathrm{N}=5$

The anxiolytic effect of SKBE may be due to a similar mechanism.

In conclusion results from this study afford scientific proof that SKBE may possess psychoactive principles with promising sedative, anticonvulsant and anxiolytic properties. Therefore, further evaluation of these psychoactive principles is recommended. 


\section{REFERENCES}

1. Theodore WR, Leonard SS. 1990. Drug effective in the therapy of the epilepsies. In: Alfred, G.G., Theodore, W.R., Alan, S.N., Palmer, T. (Eds.), The Pharmacological Basis of Therapeutics 8th edition Pergamon Press, New York, pp. 436-462.

2. Meinardi H, Scott RA, Reis R, Sander JW. 2001. The treatment gap in epilepsy: the current situation and ways forward. Epilepsia; 42: 136-49.

3. Ngugi AK, Bottemley C, Kleinschmidt I. 2010. Estimation of the burden of active and life-time epilepsy: a meta-analytic approach. Epilepsia; 51: 883-90.

4. 4. Arbonnier M. 2004. Trees, shrubs and lianas of West Africa Dry Zones. Weikersheim: Margraf Publishers.

5. Falodun A, Qadir IM., Poh CF, Omogbai EKI, Choudhary MI. 2009. Bioactive chemical constituents of Stereospermum kunthianum (Bignoniaceae). Research Journal of Phytochemistry, 3, 35-43, doi: 10.93923/rjphyto.2009.35.43.

6. Lorke D. 1983. A new approach to practical acute toxicity testing. Archive of Toxicology, 53: 275-287. http:doi.org 10.1007/bf01234480

7. Bhutada P, Mundhada Y, Bansod K, Dixit P, Umathe S, Mundhada D. 2010. Anticonvulsant activity of berberine, an isoquinoline alkaloid in mice. Epilepsy and Behaviour 18, 207-210.

8. Bienvenu E, Amabeoku GJ, Eagles PK, Scott G, Springfield EP. 2002. Anticonvulsant activity of aqueous extract of Leonotis leonurus. Phytomedicine 9, 217-223.

9. Wambebe, C. 1985. Influence of some agents that affect 5-HT metabolism and receptors and nitrazepam-induced sleep in mice. British Journal of Pharmacology 84, 185-191.

10. Rosidah Y, Yam, MF, Sadikun A, Ahmad M, Akowuah GA, Asmawi MZ. 2009. Toxicology evaluation of standardized methanol extract of Gynura procumbens. Journal of Ethnopharmacology 123, 244-249.

11. Ya'u J, Chindo BA, Yaro AH, Okhale SE, Anuka JA, Hussaini IM. 2013. Safety assessment of the standardized extract of Carissa edulis root bark in rats. Journal of Ethnopharmacology 147, 653-661.

12. Johnston GAR. 1978. Neuropharmacology of amino acid inhibitory transmitters. Annual Review of Pharmacology 18, 269-289.

13. Scholfield CN. 1982. Antagonism of gamaaminobutyric acid and muscimol by picrotoxin, bicuculine, strychnine, bemegride, leptazole, D- tubocurarine and theophylline in the isolated olfactory cortex. Archive of Pharmacology (Weinheim) 328, 274-280.

14. DeSarro A, Cecchetti V, Fravolin V, Naccari F, Tabarrini O, DeSarro G. 1999. Effects of novel 6defluoroquinolones and classic quinolones on pentylenetetrazole-induced seizures in mice. Antimicrobial Agents and Chemotherapy 43, 17291736.

15. MacDonald RL, Kelly KM. 1995. Antiepileptic drug mechanisms of action. Epilepsia 36, S2-S12.

16. Rogawski MA. 2006. Molecular targets versus models for new antiepileptic drug discovery. Epilepsy Research 68, 19-94.

17. Nevins ME, Arnolde SM. 1989. A comparison of the anticonvulsant effects of competitive and noncompetitive antagonists of the D-N-methyl-Daspartate. Brain Research 503, 1-4.

18. Velisek L, Kusa R, Kulovana M, Mares P. 1999. Excitatory amino acid antagonists and pentylenetrazole-induced seizures during ontogenesis I. The effects of 2- amino-7 phosphonoheptanoate. Life Science 46, 1349-1357.

19. White HS. 1997. New mechanisms of antiepileptic drugs II. In: Porter, R., Chadwick, D. (Eds.), Epilepsies. Butterworth Heinemann, Boston, pp. 130.

20. Gottesmann C. 2002. GABA mechanisms and sleep. Neuroscience 111, 231-239.

21. Dopp JM, Phillips GP. 2008. Sleep disorders. In: Dipiro JT, Talbert RL, Yee GC, Matzke GR, Wells BG, Posey LM. (Eds.), Pharmacotherapy: A Pathophysiologic Approach, 7th edition McGrawHill, New York, pp. 1191-1201.

22. N'Gouemo P, Nguemby-bina, C, Baldy-Moulinier M. 1994. Some neuropharmacological effects of an ethanolic extract of Maprounea africana in rodents. Journal of Ethnopharmacology 43, 161-166.

23. Nicolas LB, Kolb Y, Prinssen EPM. 2006. A combined marble burying- locomotor activity test in mice: a practical screening test with sensitivity to different classes of anxiolytics and antidepressants. European Journal of Pharmacology 547:106-15.

24. Jimenez-Gomez C, Osentoski A, Woods JH. 2011. Pharmacological evaluation of the adequacy of marble burying as an animal model of compulsion and/or anxiety. Behavioural Pharmacology 22:711-3.

25. Degroot A, Nomikos G. 2005. Fluoxetine disrupts the integration of anxiety and aversive memories. Neuropsychopharmacology 30: 391-400. 